\title{
付着割裂作用を受けるコンクリートの応力解析
}

\section{STRESS ANALYSIS OF CONCRETE SUBJECTED TO SPLITTING BOND ACTION}

\author{
角 徹三*・山田 守**
}

By Tetsuzo KAKU and Mamoru YAMADA

\begin{abstract}
In order to investigate the splitting crack patterns due to the wedge action and dowel action of deformed bars and estimate the splitting bond strength, the two-dimensional non-linear finite element analysis was carried out on reinforced concrete members. The wedge force or dowel force was replaced by uniform or non-uniform internal pressure, respectively, and the subject of analysis was limited to concrete only. Concrete cover and bar spacing were selected as analytical parameters.

The analytical results show that three splitting crack patterns proposed by Jirsa and Morita : V-notch, side splitting and corner splitting type are also observed by this analysis, and that the dowel action aggravate especially the side splitting failure. On the basis of the analytical results, a tentative equation to estimate the splitting bond strength was proposed.

Keywords : deformed bar, splitting bond failure, wedge action, dowel action, finite element analysis
\end{abstract}

\section{1. 序論}

異形鉄筋を用いた RC 柱やはりのせん断実験を行う と, 斜めひびわれの発達やコンクリートの圧壊に先行し て，主筋のかぶり部分のコンクリートが割り裂かれて部 材の耐力を失う，付着割裂破壊が起こることがある。こ の破壊は，せん断破壊と同様，エネルギー吸収能力の小 さい脆性的なモードで，破壊に対する安全性を基本とす る限界状態設計法の思想の下では好ましくないものであ る.

$\mathrm{RC}$ 部材のせん断破壊は, 鉄筋に丸鋼が使用されてい た時代から難問とされており，今日までメカニズムの解 明, 耐力式の提案に多くの労力が注がれてきた。一方, 鉄筋コンクリートの基本的性質として，付着性状に関す る研究も古くから行われてはいたが，付着作用が部材の 耐力に及ぼす影響が認識されたのは, Leonhard ${ }^{1}{ }^{1}, \mathrm{Kani}^{2}{ }^{2}$ らの研究以後である. 以来, 付着に関する研究は多岐に わたり行われるようになり，急速な発展を遂げた．その 後, 1970 年代に行われたせん断実験 ${ }^{3}$ において, 多くの

* 正会員 工博 豊橋技術科学大学助教授 建設工学系 （ ₹440 豊橋市天伯町字雲雀ヶ丘 1-1）

** 学生会員 工修 豊橋技術科学大学大学院工学研究科博士 課程 (同上)
試験体でせん断破壊とはかなり異なる性状の破壊が認め られたことにより， RC 部材の脆性的な破壊としての付 着割裂破壊が，新たにクローズアップされてきたのであ る.

しかし, 付着とせん断の相互作用は甚だ複雑で, 主筋 のだぼ作用 (dowel action), 横補強筇の影響, 部材寸 法や主筋の配置によっては, 付着割裂破壊かせん断破壊 か明瞭には区別できない場合も多い，そのため，付着割 裂破壊とせん断破壊のメカニズムは明らかに異なるにも かかわらず，現行の設計方針では，付着割裂破壊をせん 断破壊の一部として取り扱っている感がある4).わが国 の土木, 建築両分野で用いられているせん断設計式は, いずれも多くの実験データに基づくもので5)、6), 実用上, 十分な評価を受けているが，これらの式で付着割裂破壊 も有効に防げるかどうかは疑問が残るところである.

異形鉄筋の付着割裂作用に注目した解析的, 実験的研 究は, せん断破壊の研究に比べ, 非常に少ないのが現状 である. Harvill ${ }^{7)}$, Tepfers ${ }^{8}$ は, 異形鉄筋の割裂作用を 調べるために，くさび作用 (wedge action) を受ける鉄 筋周囲のコンクリートを, 内圧が作用する厚肉中空円盤 に置き換えて応力解析を行った。しかし，断面内の鉄筋 の配置については考慮されていないため, 実設計に結び

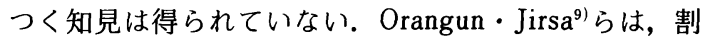


裂ひびわれの発生するパターンを，かぶりと鉄筋間のあ きの大小関係により，きわめて明瞭に分類した.しかし， その判別法は工学的判断のみによるところが多く理論的 裏付けに欠けている．森田・藤井 ${ }^{10)}$ は，カンチレバー型 の付着実験より，断面内の主筋の配置を考慮し，3 種類 のひびわれパターン別の付着割裂強度算定式を提案し た.さらに, Orangun · Jirsa ${ }^{9)}$ 式, Jimenez $\cdot$ Gergely ${ }^{11)}$ 式と比較し，実験值との適合性が優れていることを証明 した.しかしながら，これらの付着割裂強度の算定式は， いずれも影響因子一たとえば，かぶり厚さ，付着長さ， 横補強筋量一の評価が非常に異なっており，統一された 見解は得られていない。これらの式の妥当性を検証する には，実験・解析両面からのデータの蓄積が必要であろ う.

そこで，本論文は，付着割裂破壊を防ぐためのより合 理的な設計法の確立を目的として，その主たる要因であ る異形鉄筋のくさび作用および部材断面内での軸方向鉄 筋の配置に注目し，それが鉄筋周囲のコンクリートに与 える影響について二次元有限要素法により解析的研究を 行う. また，せん断と付着の相互作用の解決の足がかり として，主筋のだぼ作用の影響についても言及する.

\section{2. 解 析 概 要}

\section{（1）異形鉄筋の付着割裂メカニズム}

異形鉄筋とコンクリート間の力の伝達機構は，図一1 に示すような，ふしによる機械的な抵抗，すなわちくさ び作用であると考えてよい，このふしで鉄筋からコンク リートに作用する力に注目すると，ふしに垂直に作用す る支圧力 $f_{b}$ は, 鉄筋軸方向の成分いわゆる付着応力 $\tau_{b}$ と鉄筋軸に垂直方向で放射状に作用する応力 $\sigma_{r o}$ に分解 される.

$$
\begin{aligned}
& \tau_{b}=f_{b} \cdot \sin \theta \\
& \sigma_{r o}=f_{b} \cdot \cos \theta
\end{aligned}
$$

ここに， $\theta$ はすべり面の鉄筋軸に対する角度である.

コンクリート中の異形鉄筋が軸力を受けると鉄筋は,

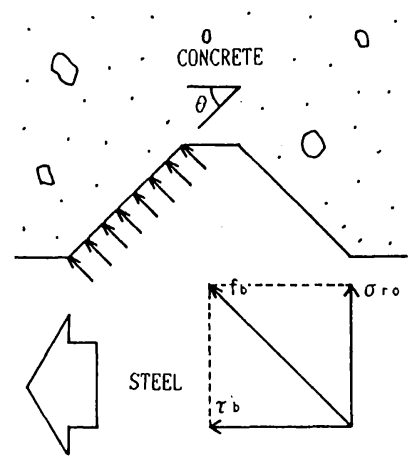

図一1＼cjkstart異形鉄筋のくさび作用

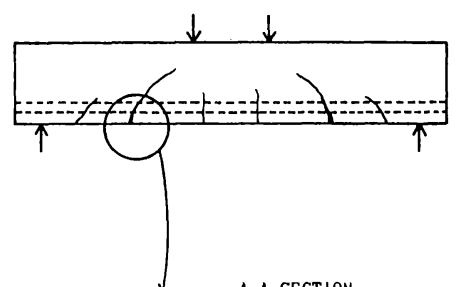

A-A SECTION

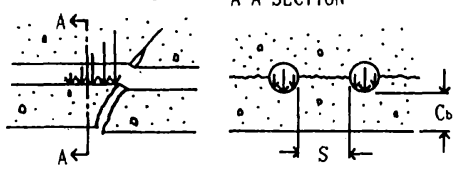

図一2 だほ作用による割裂ひびわれ

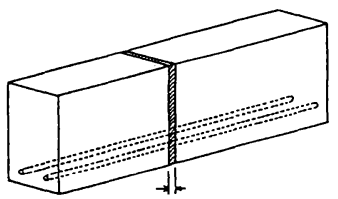

UNIT LENGTH

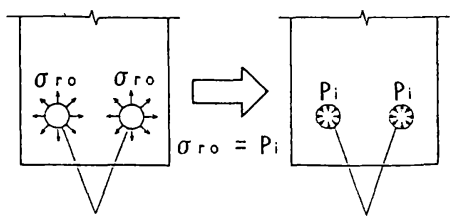

DEFORMED BAR

HOLLOW C.IRCULAR HOLE

図一3 くさび作用のモデル化 
す、コンクリートに放射方向応力 $\sigma_{r o}$ を与える鉄筋を中 空に置き換え, この部分に, $\sigma_{r o}$ に等価な内圧 $P_{i}$ を作 用させる. 解析対象は, 実験で通常観察される ${ }^{14)} \mathrm{V}$ notch split, Side split, Corner split の 3 つのひびわれ パターンを想定し，断面内の主筋の配置により図一 4 に 示す 3 つのシリーズに分ける. 表一1に解析を行った各 シリーズの断面諸寸法を示す.

$\mathrm{A}$ シリーズは, 鉄筋径 $d_{b}$ と底面かぶり厚さ $C_{b}$ の関 係が, コンクリートの応力状態に与える影響を調べるた めのものである. $C_{b}$ を変数として, 他の三方向のかぶ り厚さは十分大きくしたもので, V-notch split 型のひ びわれが予想される断面である. $C_{b} / d_{b}$ の值が， 0.5 , $0.75,1.0,1.5,2.0$ の場合について解析する.

B シリーズは, Side split 型のひびわれが予想される 断面で, 主筋が多数一列に配置された場合の鉄筋径 $d_{b}$ と鉄筋間のあき $\mathrm{S}$ の関係が，コンクリートの応力状態 に与える影響を調べるものである. $C_{b} / d_{b}=1.5$ で一定 とし, $S / d_{b}$ が $1.5,2.0,3.0,5.0$ の場合について解 析する.

C シリーズは, 断面の隅角部に鉄筋が対称に配置さ
れて Corner split 型のひびわれが予想される場合で, 底 面かぶり $C_{b}$, 側面かぶり $C_{s}$ ，および鉄筋間のあき $S$ がコンクリートの応力状態に与える影響を調べるもので ある. $C_{b} / d_{b}=C_{s} / d_{b}=1.5$ として $S / d_{b}$ を $3.0,5.0$ と した場合, $S / d_{b}=5.0$ として $C_{b} / d_{b}=C_{s} / d_{b}$ を 1.0 , 1.5, 2.0 とした場合について解析する.

\section{(3) 解析モデル}

図一 4 に示した解析対象のうち図中のハッチを施した 部分を, 8 節点アイソパラメトリック要素により図一 5 のように分割して解く. A, C シリーズは, 対称軸上の $X$ 方向変位は生じないため, 計算対象は図一5 (a), (c) に示すように断面の半分でよい，B シリーズは，断面 内に鉄筋が十分多く並んでいるとすれば，図一4（b) の $l-l^{\prime}, n-n^{\prime}$ 上の $X$ 方向変位は生じないものと考えら れ, 計算対象は図一5 (b) のようになる． $Y$ 方向の境 界条件は, 中空円に内圧が作用している状態を考えれば, 鉄筋中心点を不動点として拘束するのが最も事実に即し ているが, 本研究ではだぼ作用との組合せも考慮してい るので, 便宜的に部材上端面の $Y$ 方向変位を拘束する ことにした．試計算によると，ふしのくさび作用による

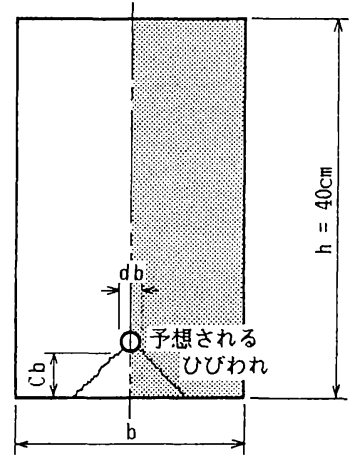

(a) A Series

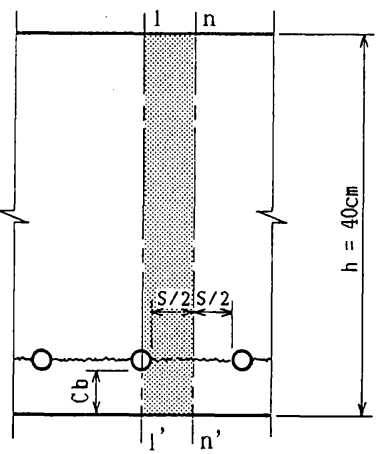

(b) B Series

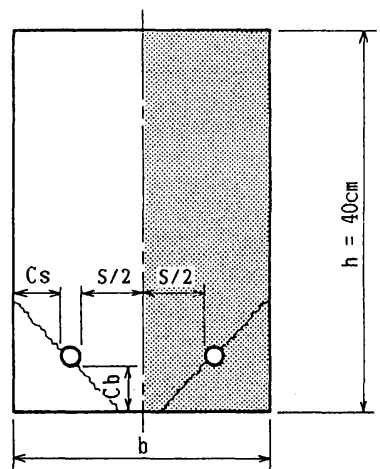

(c) C Series

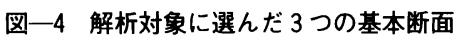

表一1断面性状

\begin{tabular}{|c|c|c|c|c|c|c|c|}
\hline Number & $\mathrm{b}(\mathrm{cn})$ & $\mathrm{Cb}(\mathrm{cm})$ & $\operatorname{cs}(\mathrm{C} \mathbf{N})$ & $\mathrm{S}(\mathrm{cm})$ & $\mathrm{Cb} / \mathrm{db}$ & $\mathrm{cs} / \mathrm{db}$ & $\mathrm{S} / \mathrm{db}$ \\
\hline$A-1$ & 30.0 & 1.0 & - & - & 0.5 & - & - \\
\hline$A-2$ & 30.0 & 1.5 & - & - & 0.75 & - & - \\
\hline$A-3$ & 30.0 & 2.0 & - & - & 1.0 & - & - \\
\hline$A-4$ & 30.0 & 3.0 & - & - & 1.5 & - & - \\
\hline$A \cdot 5$ & 30.0 & 4,0 & - & - & 2.0 & - & - \\
\hline B. 1 & - & 3.0 & - & 3.0 & 1.5 & - & 1.5 \\
\hline$B-2$ & - & 3.0 & - & 4.0 & 1.5 & - & 2.0 \\
\hline B. 3 & - & 3.0 & - & 6.0 & 1.5 & - & 3.0 \\
\hline$B-4$ & - & 3.0 & - & 10.0 & 1.5 & - & 5.0 \\
\hline$c-1$ & 18.0 & 2.0 & 2.0 & 10.0 & 1.0 & 1.0 & 5.0 \\
\hline$c-2$ & 16.0 & 3.0 & 3.0 & 6.0 & 1.5 & 1.5 & 3.0 \\
\hline$C-3$ & 20.0 & 3.0 & 3.0 & 10.0 & 1.5 & 1.5 & 5.0 \\
\hline$c-4$ & 22.0 & 4.0 & 4.0 & 10.0 & 2.0 & 2.0 & 5.0 \\
\hline
\end{tabular}

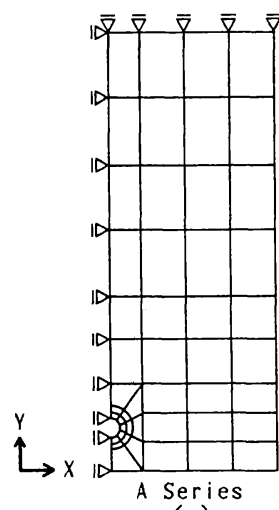

(a)

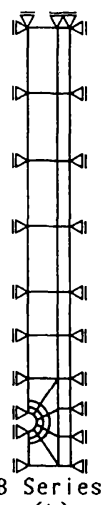

(b)

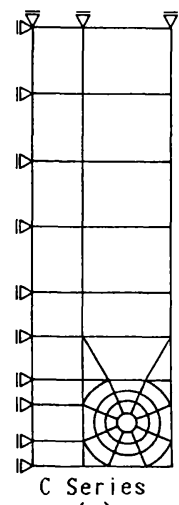

(c)

図一5 要素分割 
部材上端面近くの応力・変位は非常に小さく, 鉄筋中心 点を不動点とした場合の解析結果と全く差異はみられな かった.

コンクリート要素の応力ーひずみ構成則には, Darwin ・ Pecknold ${ }^{15}$ の提案した等価一軸ひずみ説に基 づく直交異方性モデルを, 破壊条件には, Kupfer ${ }^{16}$ のモ デルを用いる．これらのモデルは，多軸応力下のコンク リートの挙動を比較的よく表わすことができ, 多くの研 究に用いられている. 具体的な内容等は有限要素法のレ ビュー17)にも紹介されているので，ここでは省略する. 本研究で用いたコンクリートの材料定数は, 表一 2 に示 すように常識的な值とした。

鉄筋に相当する部分は, 直径 $20 \mathrm{~mm}$ の中空円とし, その円周部分には $\sigma_{r o}$ に等価な内圧 $P_{i}$ を等分布となる ように配分する. 内圧 $P_{i}$ は式 $(4)$ より $\tau_{b}$ とも等価で ある。

以上のように, RC 部材の断面を中空円を有するコン クリートのみの二次元平面応力問題に置き換えて, 異形 鉄筋の割裂作用に注目して解析を行う.

\section{表一2 コンクリートの材料定数}

\begin{tabular}{|c|c|c|c|c|}
\hline 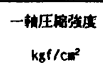 & 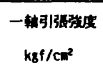 & 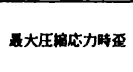 & ホアソン比 & 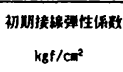 \\
\hline 300 & 30 & 0.0025 & 0.2 & $2.1 \times 10^{5}$ \\
\hline
\end{tabular}

$\left(1 \mathrm{kgf} / \mathrm{cm}^{2}=0.098 \mathrm{MPa}\right)$

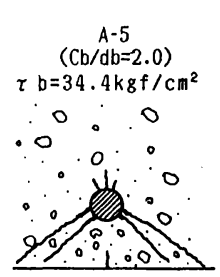

$v$-notch split

(a)

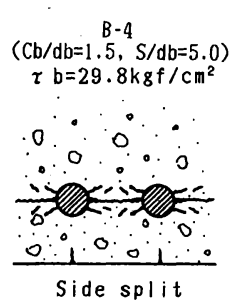

(b)
$\mathrm{C}-3$ $\tau \mathrm{b}=32.7 \mathrm{kgf} / \mathrm{cm}^{2}$

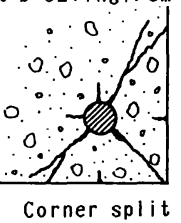

(c) $(\mathrm{Cb} / \mathrm{db}=\mathrm{Cs} / \mathrm{db}=1.5$,

図一6 典型的なひびわれパターン

\section{3. 解析結果と考察}

\section{（1）ひびわれ性状}

付着割裂破壊をひびわれパターンにより分類するた め, また，ひびわれ方向を特定することは，次節の応力 解析にも有効なため, まず, ひびわれ性状について考察 する.

図一6は，各シリーズで得られる解析結果をもとに描 いた典型的なひびわれパターンである.

A シリーズは, 鉄筋からコンクリート表面に向かっ てお互いの角度が $90^{\circ} \sim 120^{\circ}$ のいわゆるV-notch 型の ひびわれが生じている.

B シリーズでは，鉄筋軸を連ねたラインでのひびわ れが隣の鉄筋から発生するひびわれと，明らかにつな がっているのが観察される.

$\mathrm{A}, \mathrm{B}$ 両シリーズの解析結果は, 予想したひびわれパ

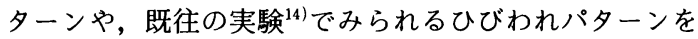
ほぼ正確に再現している。 しかし，Cシリーズの解析 結果は，これまで周知されているコンクリート隅角部を $45^{\circ} \sim 70^{\circ}$ に割り裂く corner split 型のひびわれとともに, コンクリート隅角部に進展するひびわれがみられるのが 特徴的である. 実際の実験でこのようなひびわれが観察

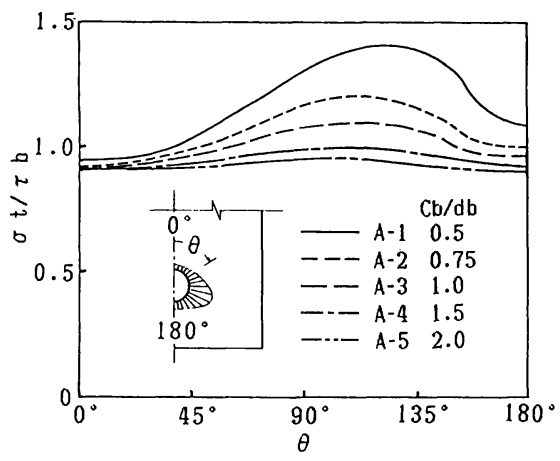

図一7 円周方向の応力分布 (A series)

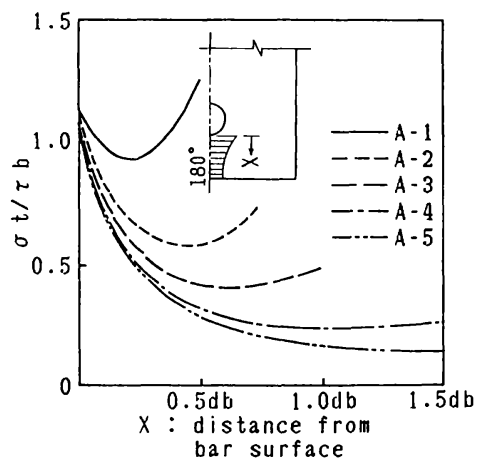

図一8 $\theta=180^{\circ}$ 方向の応力分布 (A series)

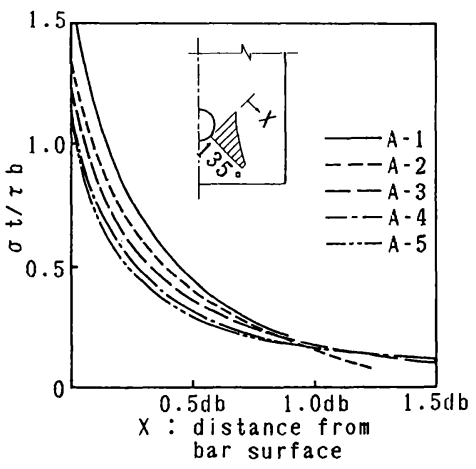

図一9 ひびわれ方向 $\left(\theta=135^{\circ}\right)$ の応力分布 (A series)

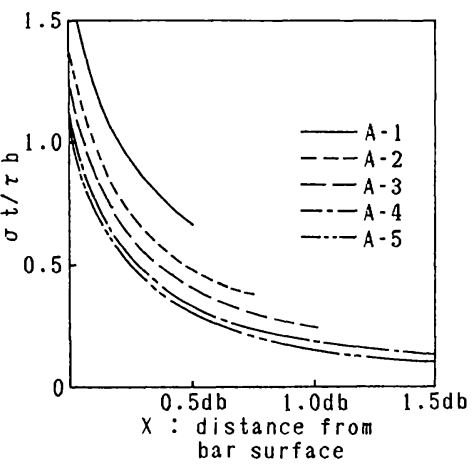

図一10 Disk Theory による応力分布 (A series) 
されるかどうかについては，著者らはまだ知り得ていな い.

また，すべてのシリーズで，鉄筋からコンクリート表 面に向かって進展し直接破壊につながるひびわれ以外 に，鉄筋真下あるいは真横のかぶり部分のコンクリート 表面からひびわれが発生する現象がみられた。この原因 については次節で考察する.

実験等で観察される付着割裂ひびわれは，ふしによる 漏斗状の内部ひびわれの影響やスターラップの存在によ り,複雑なものとなってコンクリート表面に現われるが, 異形鉄筋のくさび作用による割裂ひびわれのパターン は，大局的にはこの 3 つに分類できることが解析の面か らも実証された。

\section{（2）内圧のみによる応力解析結果}

ここでは，ひびわれ前のコンクリートの応力状態につ いて考察する. 本解析で用いたコンクリートモデルの場 合, ひびわれ前の $\sigma_{t}$ と $\tau_{b}$ の関係はほとんど線形となる. そのため, 応力解析の結果は $\sigma_{t} を \tau_{b}$ で無次元化した数 值で表わすことにする.

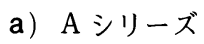

図一7〜10に A シリーズの応力解析の結果を示す.

図一7 は，鉄筋表面に最も近い積分点（鉄筋表面から $0.03 d_{b}$ ) における引張応力の円周方向の分布を示した ものである. $\sigma_{t} / \tau_{b}$ が最大となる角度は, 底面かぶり厚 さの大小により移動するが， $120^{\circ} \leqq \theta \leqq 135^{\circ}$ の範囲にあ

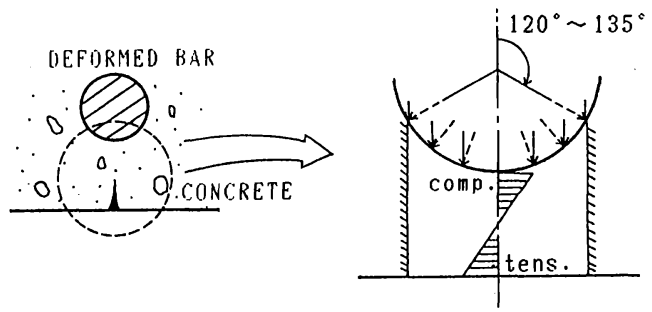

図一11かぶりコンクリートのはり作用
り V-notch ひびわれ方向と一致する.

図一8は，鉄筋とコンクリート表面との最短距離を結 んだライン $\left(\theta=180^{\circ}\right)$ 上での $\sigma_{t} / \tau_{b}$ を $C_{b}$ をパラメーター として表わしたものである．どの場合も鉄筋表面から離 れるに従って $\sigma_{t} / \tau_{b}$ は急激に減少するが，コンクリート 表面に近づくと逆に増大し始めるのが特徴である.特に, かぶりの最も小さい $C_{b}=0.5 d_{b}$ の場合は, コンクリー 卜表面近くの応力の方が鉄筋表面近くの応力よりも大き くなっている．また，鉄筋表面近くでは， $\sigma_{t} / \tau_{b}$ の大き さはどの場合もさほどの差はみられないが，鉄筋表面か ら離れてくるとかぶり厚さの影響が現われている.

図一9 は，3.（1）で得られた結果から，ひびわれ角 度を $\theta=135^{\circ}$ とし, その方向の応力分布を表わしたもの である．図一10は，鉄筋半径を内半径とし，かぶり厚 さと鉄筋半径の和を外半径とした厚肉中空シリンダーの 弾性理論式 (Disk Theory) ${ }^{13)}$ 式 (5) から求めた応力 分布である。

$$
\sigma_{t} / \tau_{b}=\frac{a^{2}}{b^{2}-a^{2}}\left(1+\frac{b^{2}}{x^{2}}\right)
$$

ここに, $a:$ 内半径 $\left(=d_{b} / 2\right)$

$b:$ 外半径 $\left(=C_{b}+d_{b} / 2\right)$

$d_{b}:$ 鉄筋径

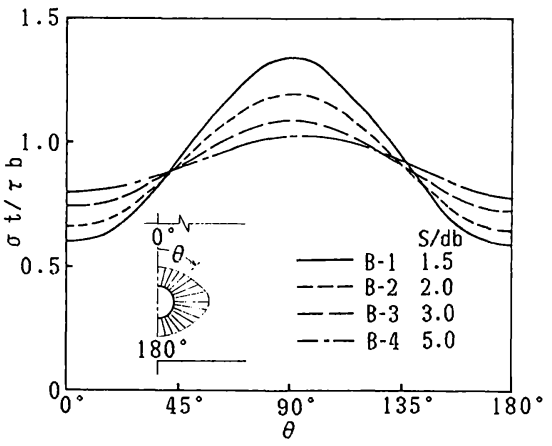

図一12 円周方向の応力分布 (B series)

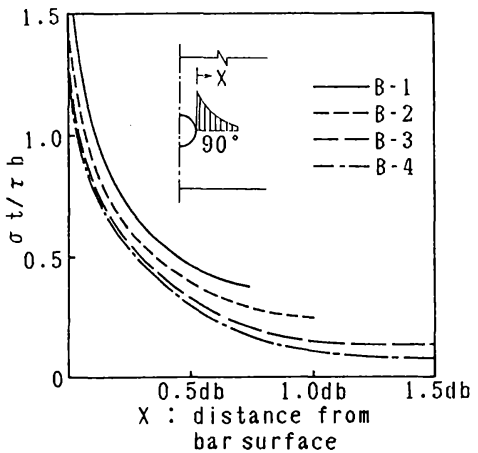

図一13 ひびわれ方向 $\left(\theta=90^{\circ}\right)$ の応力分布 (B series)

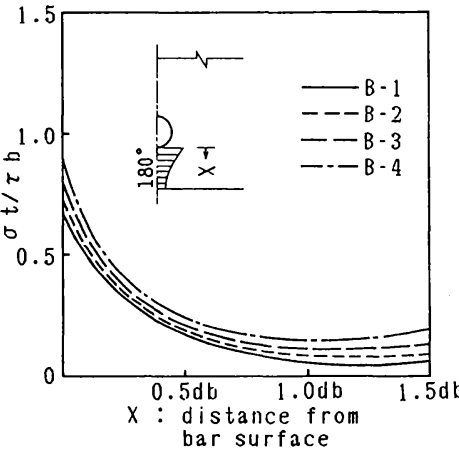

図一14 $\theta=180^{\circ}$ 方向の応力分布 (B series)

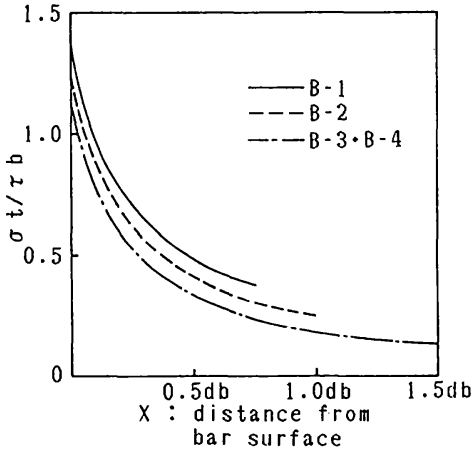

图一15 Disk Theoryによる応力分布 (B series) 


\section{$C_{b}:$ かぶり厚さ \\ $x:$ 鉄筋中心からの距離}

図一8,9 と図一10を比べると,ひびわれ方向 $\left(\theta=135^{\circ}\right)$ の応力状態は比較的 Disk Theory と一致しているが, かぶりコンクリート部分は, Disk Theory では説明でき ない応力状態となっている．特に，かぶり厚さの薄い場 合にその傾向が顕著である.

このような傾向が生じる原因を図一11で説明する. かぶり部分のコンクリートは, 鉄筋から作用する内圧 $P_{i}$ の垂直成分を分布荷重とし, $120^{\circ} \leqq \theta \leqq 135^{\circ}$ の部分で 固定されたようなはりの応力状態に類似したものとな る.このはり作用による引張応力とくさび作用によるリ ングテンション $\sigma_{t}$ が複合して, Disk Theory では説明 できないかぶり部分の応力状態が生じると考えられる. したがって，かぶり厚さが小さいとはり作用が支配的と なり，逆にかぶりが十分あればリングテンションが支配 的となり Disk Theoryに近づくのであろう。また，は り作用によって生じたコンクリート表面の引張応力は, 3. (1) で述べた鉄筋直下のコンクリート表面から進展 するひびわれの原因になると考えられる。

b) $\mathrm{B}$ シリーズ

図一12〜15にB シリーズの解析結果を示す.
図一12 は, A シリーズの場合同様に主引張応力の円 周方向の分布を示したものである. どの場合も, $\sigma_{t} / \tau_{b}$ は $\theta=90^{\circ}$ すなわち, 鉄筋軸を連ねるラインで最大とな り，その值は鉄筋間隔が小さくなるほど大きくなる．逆 に $\theta=0^{\circ}$ と $\theta=180^{\circ}$ の位置では鉄筋間隔が小さくなるほ ビ $\sigma_{t} / \tau_{b}$ は小さくなっている.

図一13 は $\theta=90^{\circ}$ 方向の応力分布, 図一14 は $\theta=180^{\circ}$ の応力分布を示したものである. 図一15 は, Disk Theoryによって求めた応力分布である， $\theta=180^{\circ}$ 方向 の応力分布をみると, $\mathrm{A}$ シリーズほど顕著ではないが,

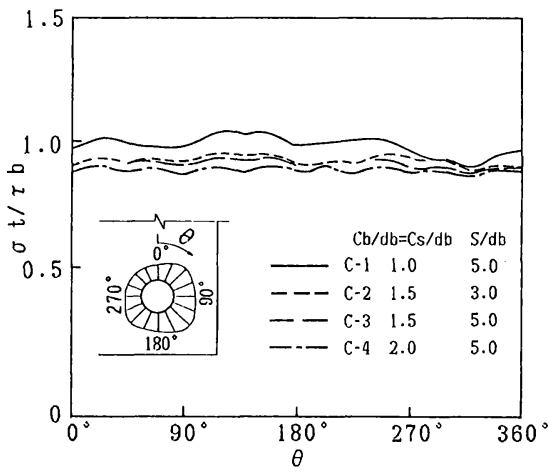

図一16 円周方向の忍力分布 (C series)

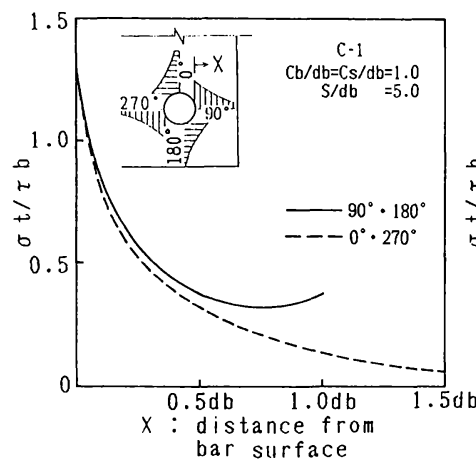

图一17 C-1 の応力分布

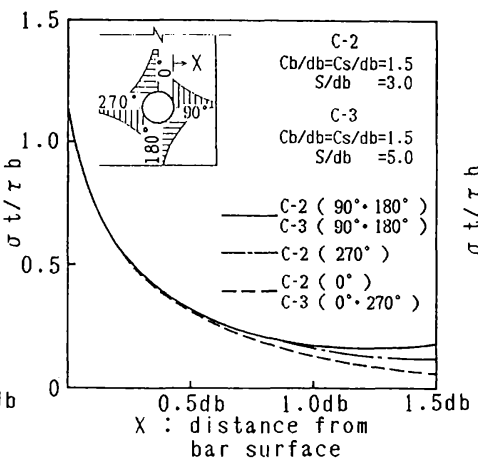

图-18 C-2・C-3 の応力分布

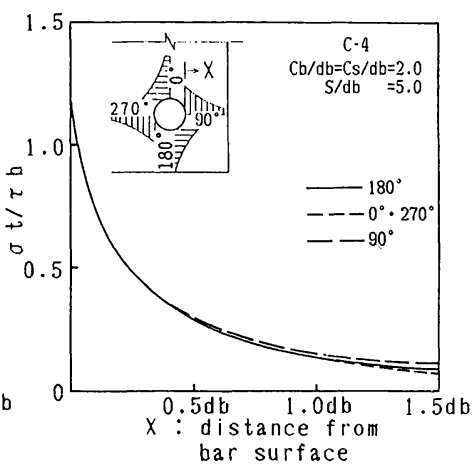

図-19 C-4 の応力分布

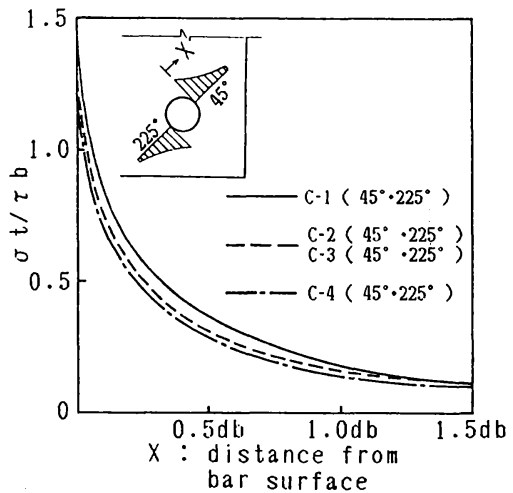

図一20 ひびわれ方向の応力分布 (C series)

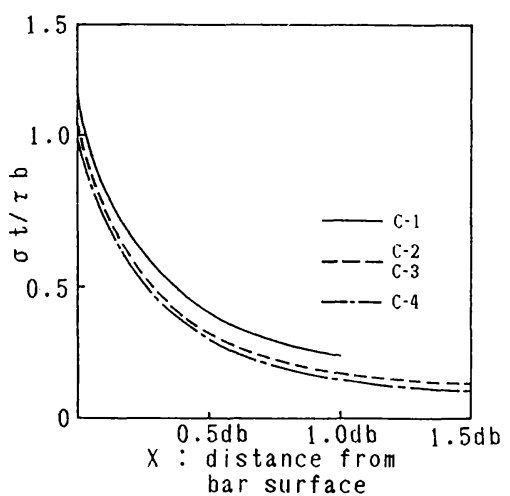

図一21 Disk Theoryによる応力分布 (C series) 
コンクリート表面近くで $\sigma_{t} / \tau_{b}$ が増加する傾向があり, ここでもわずかではあるが，はり作用が生じているのが わかる. $\theta=90^{\circ}$ 方向, すなわちひびわれ方向の応力分 布はDisk Theory と比較的一致している.

以上の結果からも，Bシリーズでは，鉄筋軸を連ねる ラインでのひびわれが他の方向のひびわれよりも先行す ることがわかる.

c) Cシリーズ

図一16〜21にC シリーズの解析結果を示す.

図一16 は主引張応力の円周方向の分布を表わしたも のである. どの場合も $\theta=45^{\circ}, 135^{\circ}, 225^{\circ}$ 付近で $\sigma_{t} / \tau_{b}$ がピーク值を示すが, 円周方向の応力変化は少なく, 他 のシリーズほど大きなピークを示していない.

図一17〜19 は $\theta=0^{\circ}, 90^{\circ}, 180^{\circ}, 270^{\circ}$ の方向の応力 分布を,かぶり厚さ別に表わしたものである.他のシリー ズ同様, コンクリート表面近くで $\sigma_{t} / \tau_{b}$ が増加し, 特に かぶり厚さの小さい場合にその傾向が強い， $C_{b}, C_{s}$ は 同じで, $S$ が異なる C-2 と C-3 の応力状態を比較する と, $\theta=270^{\circ}$ 方向のコンクリート表面近くでわずかに異 なるだけで, ほとんど同じである.このC シリーズの 場合, 鉄筋間のあきはかぶり厚さの 2 倍以上あれば, コ ンクリートの応力状態にはさほど影響を与えないといえ る.

図一20 は, 3. ( 1 ) よりひびわれ方向を $\theta=45^{\circ}, 225^{\circ}$ とし, その方向の応力分布を示したものである. 図一17 ～図一20と図一21 の Disk Theoryによる応力分布を比 較すると, ひびわれ方向の応力分布は Disk Theory と

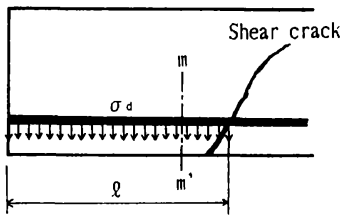

(a)

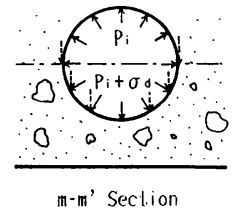

(b)
図一22 だぼ作用のモデル化
一致しているが, 他の方向, 特にかぶり厚さの小さい場 合に Disk Theory では説明できない分布となっている. これもかぶりコンクリートのはり作用による影響であろ う.

\section{（3）内圧とだぼ作用の組合せの応力解析結果}

ここでは，だぼ作用がくさび作用による応力状態によ゙ のような影響を及ぼすか，（2）の解析同様にひびわれ 前の応力状態を調べる. 主筋のだぼ作用が分担するせん 断抵抗の割合は, 作用せん断力の大きさにより変化する が，野口の実験 ${ }^{18)}$ を参考にして降伏せん断力の約 $20 \%$ と考える. 断面内に複数の鉄筋が配置されている場合, だぼ作用がおのおのの鉄筋に均等に働くものとすれば,

$$
V_{d}=0.2 \tau_{b} \cdot u \cdot z
$$

ここに， $V_{d}:$ 主筋一本に作用するせん断力

$$
\begin{aligned}
& \tau_{b}: \text { 付着応力 } \\
& u: \text { 主筋一本の周長 } \\
& z: \text { 応力中心間距離 }
\end{aligned}
$$

さらに, 解析対象とした単位長さの任意の切片に作用す る応力を導くため, 式 (6) の力が図一22（a）に示す ように, 鉄筋下半面の円周に, 付着長さ $l$ にわたて均 等に支持されると仮定すれば， $m-m^{\prime}$ 断面では

$$
\sigma_{d}=0.4 \tau_{b} \cdot z / l
$$

の応力が作用している. 上式に本研究で用いた断面 $\left(C_{b} / d_{b}=1.5\right)$ より, $z=31.5 \mathrm{~cm}$ を代入し $\sigma_{d}=12.6 \tau_{b} / l$.

が得られる.

本解析では図一22（b）に示すように, 内圧とだぼ作 用を組み合わせて作用させるのであるが, その比率は, 式( 8 )の $l=50 \mathrm{~cm}$ としたときの $\sigma_{d}=0.252 \tau_{b}$ に基づき, $\sigma_{d} / \tau_{b}$ が $0.1,0.2,0.3$ の 3 通りとした.

図一23〜25にひびわれ方向での応力分布を示す. 各 シリーズとも $\sigma_{d} / \tau_{b}$ に比例して $\sigma_{t} / \tau_{b}$ が増加するが, そ の割合は $\sigma_{d} / \tau_{b}=0.1$ に対して, $\mathrm{A}$ シリーズで $5.6 \%$, $\mathrm{B}$ シリーズで $17.4 \%, \mathrm{C}$ シリーズでは $6.0 \%$ となって いる.だぼ作用は, 明らかに鉄筋の付着に対して不利で

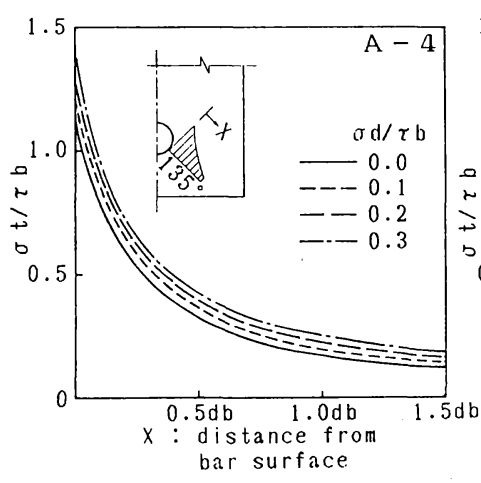

図一23だぼ作用の影䈏 (A series)

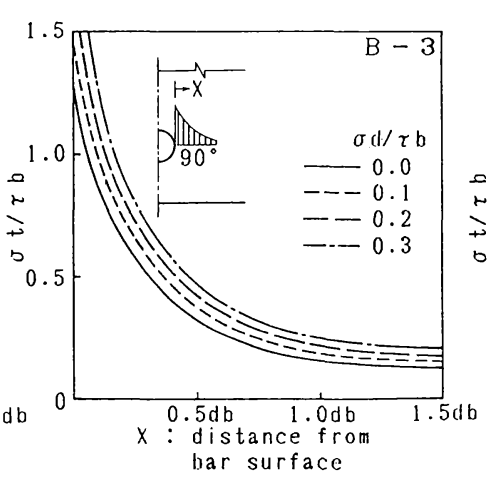

図一24だほ作用の影節 (B series)

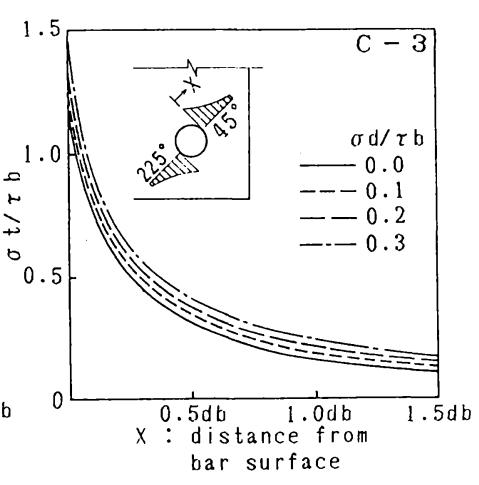

図一25だぼ作用の影敚 (C series) 
表一3 森田らの実験との比較

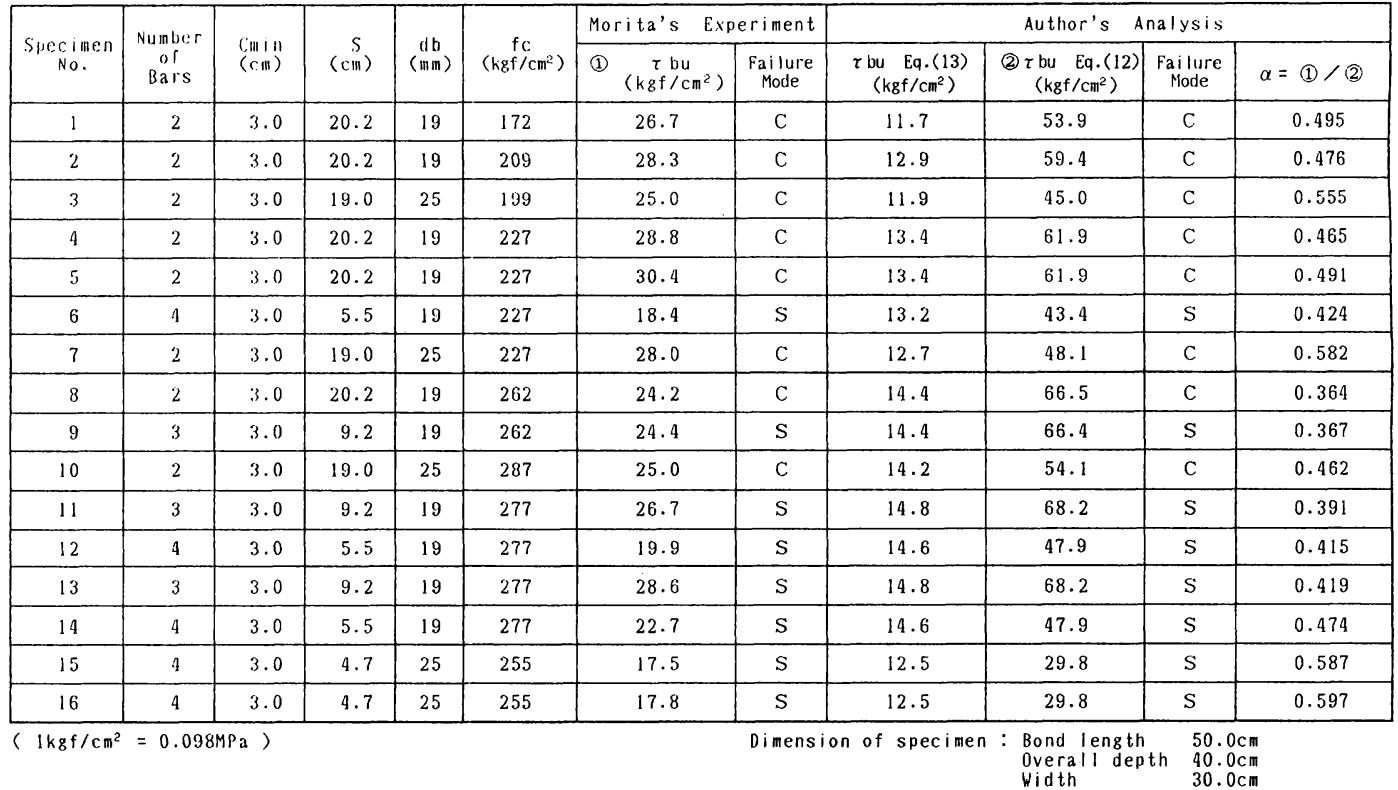

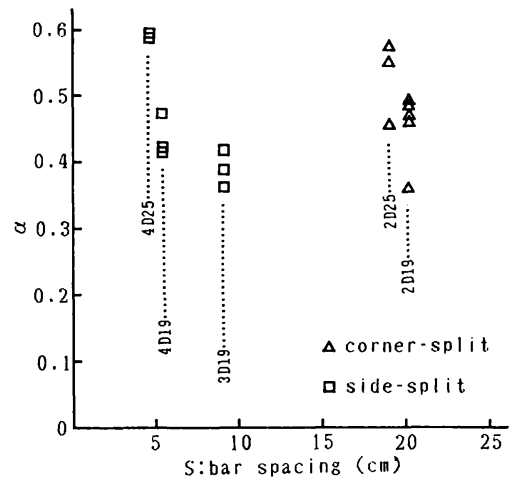

図一26 $\quad \alpha$ と鉄筋間のあきの関係

あり，特に鉄筋の配置により side split 型のひびわれが 予想される場合は，付着割裂破壊を著しく助長すること になる。

\section{4. 付着割裂強度の推定}

3. ( 1 ),（ 2 ）の結果から断面内の鉄筋の配置により, 周囲のコンクリートの応力状態が全く異なり，ひびわれ パターンや，せん断力に対する抵抗に差異が生じること がわかった．特に B シリーズ (side split 型ひびわれ) の断面では，鉄筋間のあきが十分あっても，鉄筋軸を連 ねるひびわれが発生しやすく，鉄筋のだぼ作用により割 裂破壊が助長される.

ここでは,これまでの解析結果をもとに, 付着割裂強 度の算定法について考察する. 考察にあたり以下の仮定 をたてる.
(1) 3.（1）より, side split 型のひびわれ角度は $\theta=$ $90^{\circ}$, corner split 型のひびわれ角度は $\theta=45^{\circ}$ とす る.

(2) 3.（2）より，ひびわれ方向の応力分布は式（5) の Disk Theoryによって表わせる.

(3) 鉄筋軸方向の付着応力の分布は一定である.

なお，断面内に主筋が一本のみとした A シリーズ (V-notch split 型) は, 実際の設計に現われる例はほ とんどなく，実用的な意義が薄いので除外する.

仮定 (2) 上り, ひびわれ面での平均応力は,

$$
\sigma_{t \cdot \mathrm{av}}=\frac{\tau_{b}}{l_{c r}} \int_{a}^{l_{c r+a}} \frac{a^{2}}{b^{2}-a^{2}}\left(1+\frac{b^{2}}{x^{2}}\right) d x
$$

ここに, $l_{c r}:$ ひびわれ長さ

最大応力は，鉄筋表面のコンクリートに生じ

$$
\sigma_{t \cdot \max }=\tau_{b} \cdot \frac{a^{2}}{b^{2}-a^{2}}\left(1+\frac{b^{2}}{a^{2}}\right)
$$

となる，異形鉄筋によるコンクリートの割裂強度を $f_{s \rho}$ とすれば, 付着割裂破壊が発生する条件は, 式 $(9)$ に おいて $\sigma_{t \cdot \mathrm{av}}=f_{s p}$ となるとき, 式（10）において $\sigma_{t \cdot \max }$ $=f_{s p}$ となるときの 2 通りが考えられる. $f_{s p}$ は, 異形 鉄筋の横ふしから発生する内部ひびわれの影響等によ り，一軸引張強度より小さく

$$
f_{s p}=\alpha \sqrt{f_{c}} \quad(\alpha<1.0)
$$

と表わせるであろう. $\alpha$ の值は, 主に内部ひびわれの発 生状況に影響を受けると考えられるが，内部ひびわれは 横ふしの形状や間隔, 打設したコンクリートの状態等の 要因で発生状況が異なり,これらの関数として $\alpha$ を決 


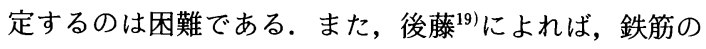
水平間隔により内部ひびわれの発生状況が異なり, その 内部ひびわれにより形成されたくし歯コンクリートの変 形作用が割裂ひびわれを発生される原因の 1 つであると している. すなわち, 鉄筋間のあきにより $\alpha$ の值が変 化することも予想される.

式（10）と式（11）より付着割裂強度 $\tau_{b u}$ は, 破壊条 件に $\sigma_{t \cdot \mathrm{av}}=f_{\text {sp }}$ を用いた場合

$$
\tau_{b u}=\frac{\alpha \cdot l_{c r} \cdot \sqrt{f_{c}}}{\frac{a^{2}}{b^{2}-a^{2}}\left(l_{c r}+\frac{b^{2}}{a}-\frac{b^{2}}{l_{c r}+a}\right)}
$$

破壊条件に $\sigma_{t \cdot \max }=f_{s \rho}$ を用いた場合

$$
\tau_{b u}=\frac{\alpha \cdot \sqrt{f_{c}}}{\frac{a^{2}}{b^{2}-a^{2}}\left(1+\frac{b^{2}}{a^{2}}\right)}
$$

となる。

式 (12) のひびわれ長さ $l_{c r}$ は, 仮定 (1)より ${ }_{s} l_{c r}=s / 2 \quad$ (side split 型) $(14 \cdot a)$

${ }_{c} l_{c r}=\sqrt{2}\left(C_{\min }+d_{b} / 2\right)-d_{b} / 2 \quad$ (corner split 型)

\section{ここに, $S:$ 鉄筋間のあき}

$$
C_{\min }: \text { 最小かぶり }
$$

ひびわれパターンが side split 型になるか corner split 型になるかは ${ }_{s} l_{c r}$ と ${ }_{c} l_{c r}$ の大小関係によって決ま る. 式 (14) より

$$
C_{\mathrm{min}}>\frac{\sqrt{2}}{4} S+\frac{\sqrt{2}-2}{4}
$$

のとき side split 型

$$
C_{\min }<\frac{\sqrt{2}}{4} S+\frac{\sqrt{2}-2}{4}
$$

のとき corner split 型となる.

表一3 は森田・藤井の横補強筋のないカンチレバー型 付着試験の結果 ${ }^{14)}$ と式 (12), 式 (13) を比較したもの である。

式（13）による $\tau_{b u} / \alpha$ は実験値よりかなり小さく, $\alpha$ は 1.0 より大きくなり矛盾が生じる.これは, 鉄筋軸方 向の付着応力分布の仮定に起因すると考えられる. すな わち，実験では鉄筋軸方向の付着応力分布は一様にはな らず, 破壊を生じた部分から順次応力の再分配が行われ て最終的な破壊に至るが, 計算では鉄筋軸方向の付着応 力分布は一定とし, 付着長さ全長にわたり同時に破壊す ると仮定したためであろう. 付着割裂破壊が発生する条 件を $\sigma_{t} \cdot \max =f_{s p}$ とするには, 鉄筋軸方向の付着応力分 布, 破壊後の応力の再分配を何らかの形で考慮する必要 があろう.また式（13）では，ひびわれパターンの判別 ができないという短所がある.

一方, 式 (12) による $\tau_{b u} / \alpha$ は実験值よりも大きくな
り， $\alpha$ を用いれば実験結果を説明できる. 式 (15), (16) による判別法も実験でのひびわれパターンと一致してい る.

式(12)を用いれば $\alpha$ の平均值は, side split 型で 0.46, corner split 型では 0.49 と大きな差はみられない. 鉄筋 間のあきと $\alpha$ の関係を図一26に示すが，相関関係はな いようである.むしろ, 同じ, コンクリートを打設した 供試体の $\alpha$ の值が非常に近いことを考えると, $\alpha$ は, コ ンクリートの打設状況, 締め固めの程度, 空気量等に大 きく依存するものと考えられる. 式 (12) に $\alpha_{\mathrm{av}}=0.47$ を代入して, 横補強筋のない場合の付着割裂強度式

$$
\tau_{b u}=\frac{0.47 \cdot l_{c r} \cdot \sqrt{f_{c}}}{\frac{a^{2}}{b^{2}-a^{2}}\left(l_{c r}+\frac{b^{2}}{a}-\frac{b^{2}}{l_{c r}+a}\right)}
$$

が得られる.しかし， $\alpha$ には上述の割裂破壊発生の条件, 鉄筋軸方向の付着応力分布の仮定の影響も含まれている 可能性もあり，これらをいかに評価するかが問題点とし て残る.

\section{5. 結 論}

異形鉄筋のくさび作用およびせん断力による dowel action が，鉄筋周囲のコンクリートにどのような影響 を与えるか二次元有限要素法で解析し, 以下のような結 論を得た。

（1）異形鉄筋のくさび作用による付着割裂ひびわれ は, Darwin-Pecknold モデルを用いた解析より図一6の 3 種類が得られた. これは, 実験で観察される他の要因 を含んだ複雑なひびわれパターンの基本となるものであ る.

（2）かぶり部分のコンクリート表面には, Disk Theory では説明できない引張応力が生じる.これは, かぶりコンクリートのはり作用の影響と考えられる. 鉄 筋直下のコンクリート表面には，このはり作用によるひ びわれが発生する.

（３）ひびわれ方向の主引張応力分布は, どのひびわ れパターンにおいても Disk Theoryによって表わすこ とができる.

（4） side split 型のひびわれが予想される断面では, 他の 2 つのひびわれが予想される断面に比べ，だぼ作用 が割裂ひびわれを著しく助長する.

（5）式 (15),（16）により, 断面内の鉄筋の配置か ら, side split 型と corner split 型のひびわれパターン の判別が可能である.

（6）式（17）により, 横補強筋のない場合の付着割 裂強度の推定が可能である. 
1) Leonhaldt, F. and Walther, R. : Contributions to the treatment of the problems of shear reinforced concrete construction, Translation No.111, Cement and Concrete Association, London, 1964.

2) Kani, G. N.J. : The riddle of shear failure and its solution, Journal of ACI, pp.441 467, Apr. 1964.

3) 建設省建築研究所 : 建築構造部材の耐震強度の解析（鉄 筋コンクリート柱の勒性の向上について (その 3$))$, 建 設省建築研究所報告書, 1977 年 3 月.

4）土木学会 : コンクリート構造の限界状態設計法指針(案), コンクリート・ライブラリー第 52 号, 昭和 58 年 10 月.

5) Okamura, H. and Higai, T. : Proposed design equation for shear strength of reinforced concrete beams without web reinforcement, Proc. of JSCE, No.300, pp.131 141, Aug. 1980.

6）荒川 卓：鉄筋コンクリート梁のせん断抵抗に関する研 究, 日本建築学会論文集, 第 66 号, pp. 437 440, 昭和 35 年 10 月.

7) Harvill, Jr. P.S. : The nature of bond splitting in reinforced concrete, Ph-D Thesis, Univ. of Colorado, 1964.

8) Tepfers, R. : Cracking of concrete cover along anchored deformed reinforcing bars, Magazine of Concrete Research, Vol.31, No.106, pp.3 12, Mar. 1979.

9) Orangun, C. O., Jirsa, J. O. and Breen, J. E. : A reevaluation of test data on development length and splices, ACI Journal, Proc. Vol.74, Mar. 1977.

10）藤井 栄・森田司郎：異形鉄筋の付着割裂強度に関する 研究一第 2 報 付着割裂強度算定式の提案一, 日本建築 学会論文報告集, 第 300 号, pp. $45 \sim 53$, 昭和 58 年 2 月.
11) Jimenez, R., White, R. N. and Gergely, P. : Bond and dowel capacities of reinforced concrete, ACI Journal, Proc. Vol.76, Jan. 1979.

12) Lutz, L. A. and Gergely, P. : Mechanics of bond and slip of deformed bars in concrete, ACI Journal, Vol.64, No. 11, pp. 711 721, Nov. 1967.

13) Timoshenko, S. and Goodier, J. N. : Theory of Elasticity, Second edition, McGraw-Hill Book Company, Feb. 1951.

14）藤井 栄・森田司郎：異形鉄筋の付着割裂強度に関する 研究一第 1 報 付着破壊を支配する要因についての実験 結果一, 日本建築学会論文報告集, 第 319 号, pp. 47 55, 1982 年 9 月.

15) Darwin, D. and Pecknold, D. A. : Nonlinear biaxial stress law for concrete, Journal of Engineering Mechanics Division, ASCE, Vol.103, No.EM 2, pp. 229 241, Apr. 1977.

16) Kupfer, H. B. and Gerstle, K. H. : Behavior of concrete under biaxial stresses, Journal of Engineering Mechanics Division, ASCE, Vol. 99, No. EM 4, pp. $852 \sim 866$, Aug. 1973

17) ASCE Task Committee : State-of-the-Art Report on Finite Element Analysis of Reinforced Concrete, ASCE, 1982.

18）野口 博・落合正雄・堀川考助：鉄筋コンクリートばり のせん断抵抗に関する研究 (第 2 報), 日本建築学会関東 支部研究報告, pp. 117 120, 1980 年.

19）後藤幸正・大塚浩司：引張を受ける異形鉄筋周辺のコン クリートに発生するひびわれに関する実験的研究, 土木 学会論文報告集, 第 294 号, pp. 85 100, 1980 年 2 月.

(1988.1.5 - 受付) 